\title{
Natural Radionuclides Determination and Radiological Hazard Assessments in Soil from Tual and Kei Islands, Indonesia
}

\author{
Syarbaini $^{1^{\star}}$, Kusdiana ${ }^{2}$, M. Wiyono ${ }^{2}$ and D. Iskandar ${ }^{3}$ \\ ${ }^{1}$ Center for Radioisotopes and Radiopharmaceutical Technology, National Nuclear Energy Agency (BATAN), \\ Puspiptek Area Serpong, Tangerang Selatan 15314, Indonesia \\ ${ }^{2}$ Center for Radiation Safety Technology and Metrology, National Nuclear Energy Agency (BATAN), \\ Jl. Lebak Bulus Raya No. 49, Jakarta 12440, Indonesia \\ ${ }^{3}$ Center for Radioactive Waste Technology, National Nuclear Energy Agency (BATAN), \\ Puspiptek Area Serpong, Tangerang Selatan 15314, Indonesia
}

\section{ARTICLE INFO}

Article history:

Received 28 October 2019

Received in revised form 19 April 2020

Accepted 24 April 2020

Keywords:

Soil

Natural radioactivity

Gamma spectrometry

Radiological hazards

\begin{abstract}
A B S T R A C T
Natural radionuclides ${ }^{226} \mathrm{Ra},{ }^{232} \mathrm{Th}$ and ${ }^{40} \mathrm{~K}$ in soil are the primary component of the background exposure sources of the population. Study of the external exposure due to gamma-ray radiation of natural radionuclides is important because this may contribute significantly to the total annual individual dose. The purpose of this study is to investigate the natural radionuclides in soils collected from Tual and Kei islands and assess the radiological hazard due to natural radionuclides contents in soil. The soil samples were analyzed for natural radionuclides ${ }^{226} \mathrm{Ra},{ }^{232} \mathrm{Th}$ and ${ }^{40} \mathrm{~K}$ using gamma ray spectrometry. Radiological hazard parameters were estimated from the activity concentration of these radionuclides in order to assess health implication of exposure of the general public. The activity concentrations of ${ }^{226} \mathrm{Ra}$, ${ }^{232} \mathrm{Th}$ and ${ }^{40} \mathrm{~K}$ in soil samples varied from $7.50 \mathrm{~Bq} \mathrm{~kg}^{-1}$ to $6326 \mathrm{~Bq} \mathrm{~kg}^{-1}, 0.99 \mathrm{~Bq} \mathrm{~kg}^{-1}$ to $157 \mathrm{~Bq} \mathrm{~kg}^{-1}, 2.97 \mathrm{~kg}^{-1}$ to $98.91 \mathrm{~Bq} \mathrm{~kg}^{-1}$ with the average value of $2162 \mathrm{~Bq} \mathrm{~kg}^{-1}$; $69.68 \mathrm{~Bq} \mathrm{~kg}^{-1}$ and $30.74 \mathrm{~Bq} \mathrm{~kg}^{-1}$, respectively. The absorbed dose rates due to the presence of ${ }^{226} \mathrm{Ra},{ }^{232} \mathrm{Th}$ and ${ }^{40} \mathrm{~K}$, in soil samples in the studied area vary between the range of $4.88 \mathrm{nGy} \mathrm{h}^{-1}$ and $3018.80 \mathrm{nGy} \mathrm{h}^{-1}$ with the average value of $1042 \mathrm{nGy} \mathrm{h}^{-1}$. The corresponding outdoor annual effective doses ranged between $0.01 \mathrm{mSv} \mathrm{y}^{-1}$ and $3.70 \mathrm{mSv} \mathrm{y}^{-1}$ with the average value of $1.28 \mathrm{mSv} \mathrm{y}^{-1}$. Radium equivalent activities are calculated to be in the range of $10.42 \mathrm{~Bq} \mathrm{~kg} \mathrm{~kg}^{-1}$ $-6553.03 \mathrm{~Bq} \mathrm{~kg}^{-1}$ with the average value of $2264 \mathrm{~Bq} \mathrm{~kg}^{-1}$. The external and internal hazard indexes vary from 0.03 to 17.71 with the average value of 6.12 and 0.05 to 34.81 with the average value of 11.96 , respectively. All calculated average radiological hazard indices were higher than the limits recommended for individual members of the public.
\end{abstract}

(C) 2020 Atom Indonesia. All rights reserved

\section{INTRODUCTION}

The naturally occurring radionuclides are distributed in the environment with different concentration depend on the local geology of each region [1,2]. Natural radionuclides arise mainly from primordial radionuclides ${ }^{232} \mathrm{Th},{ }^{238} \mathrm{U}$, their decay products and ${ }^{40} \mathrm{~K}$, which are found everywhere in almost all ground formations. Primordial radionuclides have long half-lives so that they decay to reach a stable state emitting ionizing

*Corresponding author.

E-mail address: sarbaini@batan.go.id

DOI: https://doi.org/10.17146/aij.2020.995 radiations for a sufficiently long time $[3,4]$. Gamma-ray radiation emitted from such natural radionuclides is present in all soil and represents the main external exposure of radiation to the human body. The activity concentration of natural radionuclides and their daughter products in soil is one of the main components of the natural background radiation and responsible for external exposure to the population $[5,6]$.

There are some areas in the world wherein the background radiation levels have been found to be abnormally high. Such areas are referred to as high background radiation areas such as Yangjiang, China; Kerala India; Guarapari, Brazil; and Ramsar, 
Iran [7-9]. Inhabitants of the world's high background natural radiation areas receive radiation doses that are relatively higher than the doses in the normal background radiation areas. Sohrabi, 2013 [10] has divided the world's high background natural radiation areas into 4 categories: low $\left(<5 \mathrm{mSv} \mathrm{y}^{-1}\right)$, medium $\left(5-10 \mathrm{mSv} \mathrm{y}^{-1}\right)$, high $\left(20-50 \mathrm{mSv} \mathrm{y}^{-1}\right)$ and very high $\left(>50 \mathrm{mSv} \mathrm{y}^{-1}\right)$. The global average effective dose due to natural background radiation is $2.4 \mathrm{mSv} \mathrm{y}^{-1}$, one third of which is due to external exposure and two thirds to internal exposure [11,12].

The natural radioactivity level in soils is important for assessing the radiation exposure of the human. To evaluate the natural radioactivity level in soils, it can be determined from the ${ }^{226} \mathrm{Ra},{ }^{232} \mathrm{Th}$ and ${ }^{40} \mathrm{~K}$ concentrations. Because of the radiological effects of the uranium series are produced by radium and its daughter products about more than $98.0 \%$, the contribution from the ${ }^{238} \mathrm{U}$ and the other ${ }^{226} \mathrm{Ra}$ precursors are usually not taken into account $[12,13]$. In Indonesia, several studies have been initiated in relation to the natural radionuclides concentrations in soil and the outdoor gamma dose rate. Some surveys of activity concentrations of natural radionuclides in soils in different areas have been published [14-16]. The surveys are carried out to prepare a baseline data of the natural radionuclides background of Indonesia and determining its contribution to the annual effective dose to members of the public. In this paper, we report the activity concentrations of ${ }^{226} \mathrm{Ra},{ }^{232} \mathrm{Th}$ and ${ }^{40} \mathrm{~K}$ in surface soil samples collected from Tual and Kei islands, Indonesia and also including assessments of their contribution to the radiation dose due to their presence in the soil. Preliminary survey of the gamma ray exposure rate arising from the surface soil in some regions in Indonesia, showed that Tual and Kei islands have relatively high gamma radiation dose rate, compared to others.

\section{THEORY}

Assessment of radiological hazard parameters due to natural radioactivity such as absorbed dose rates, annual effective dose, radium equivalent activity, external and internal hazard indexes are mostly used to assess radiological implications to human body [17-20]. The absorbed dose rate in air due to gamma-rays radiation emitted from decay of radionuclides depends on the specific activity concentration of these radionuclides in soil. The absorbed dose rates in air at $1 \mathrm{~m}$ height above ground for the homogeneously distributed of ${ }^{226} \mathrm{Ra}$, ${ }^{232} \mathrm{Th}$ and ${ }^{40} \mathrm{~K}$ in the soil were computed by the activity concentration values in soil. It was calculated for the absorbed dose rates $D\left(\mathrm{nGy} \mathrm{h}^{-1}\right)$ using Eq. (1).

$$
D=0.462 C_{R a}+0.604 C_{T h}+0.0417 C_{K}
$$

Where, $C_{R a}, C_{T h}$ and $C_{K}$ are the activity concentrations $\left(\mathrm{Bq} \mathrm{kg}{ }^{-1}\right)$ of ${ }^{226} \mathrm{Ra},{ }^{232} \mathrm{Th}$ and ${ }^{40} \mathrm{~K}$ in soil samples, respectively. It is assumed that all the decay products of ${ }^{226} \mathrm{Ra}$ and ${ }^{232} \mathrm{Th}$ for the above conversion factors are in radioactive equilibrium. The conversion factors $0.462,0.604$ and 0.0417 are expressed in $\mathrm{nGy} \mathrm{h}^{-1} / \mathrm{Bq} \mathrm{kg}^{-1}$.

Based on the absorbed dose rates in air, the annual effective dose rates (E) to human body were estimated using a dose conversion factor of $0.7 \mathrm{~Sv} \mathrm{~Gy}{ }^{-1}$ and outdoor occupancy factor of 0.2. The adults spend about $80 \%$ of their time indoors, while the remaining $20 \%$ time is spent outdoors. The annual effective dose $E$ in $\mathrm{mSv} \mathrm{y}^{-1}$ is calculated using Eq. (2).

$$
E=D \times 8760 \times 0.2 \times 0.7 \times 10^{-6}
$$

where $E$ is the annual effective dose rate in air $(\mathrm{mSv}$ $\mathrm{y}^{-1}$ ) and $D$ is the value of absorbed dose rate earlier calculated from Eq. (1). 8760 is the number of hours of a year.

Radium equivalent activity $\left(R a_{e q}\right)$ hazard index is also used to assess the hazards related with soils that contain ${ }^{226} \mathrm{Ra},{ }^{232} \mathrm{Th}$ and ${ }^{40} \mathrm{~K}$. The index is developed by assuming that based on an annual exposure limit of $1 \mathrm{mSv}$ per year, $370 \mathrm{~Bq} \mathrm{~kg}{ }^{-1}$ of ${ }^{226} \mathrm{Ra}$ or $259 \mathrm{~Bq} \mathrm{~kg}^{-1}$ of ${ }^{232} \mathrm{Th}$ or $4810 \mathrm{~Bq} \mathrm{~kg}{ }^{-1}$ of ${ }^{40} \mathrm{~K}$ produce the same gamma dose rate. The radium equivalent is a widely used hazard index to describe the gamma output from mixtures of ${ }^{226} \mathrm{Ra},{ }^{232} \mathrm{Th}$ and ${ }^{40} \mathrm{~K}$ in the soil. The $R a_{e q}$ from soil materials can be calculated using Eq. (3).

$$
R a_{e q}=C_{R a}+1.43 C_{T h}+0.077 C_{K}
$$

where $C_{R a}, C_{T h}$ and $C_{K}$ are the activity concentrations of ${ }^{226} \mathrm{Ra},{ }^{232} \mathrm{Th}$ and ${ }^{40} \mathrm{~K}$ in $\mathrm{Bq} \mathrm{kg}^{-1}$, respectively. The maximum value of $R a_{e q}$ must be less than $370 \mathrm{~Bq} \mathrm{~kg}^{-1}$.

The external and internal hazard indexes $\left(H_{e x} ; H_{\text {in }}\right)$ related the radium equivalent are other radiological hazard parameters to evaluate the external exposure coming from direct gamma radiation from soils and the internal alpha dose from radon and its progeny from decay of the radium. 
The external hazard index $H_{e x}$ can be calculated using Eq. (4).

$$
H_{e x}=C_{R a} / 370+C_{T h} / 259+C_{K} / 4810 \leq 1
$$

where $C_{R a}, C_{T h}$ and $C_{K}$ are the activity concentrations of ${ }^{226} \mathrm{Ra},{ }^{232} \mathrm{Th}$ and ${ }^{40} \mathrm{~K}$ in $\mathrm{Bq} \mathrm{kg}{ }^{-1}$, respectively. This model takes into consideration that the external hazard which is caused by gammarays corresponds to a maximum radium-equivalent activity of $370 \mathrm{~Bq} \mathrm{~kg}{ }^{-1}$ for the soil material. The external hazard index should be below the unity for the radiation hazard to be negligible.

Internal exposure which is caused by the inhalation of radon $\left({ }^{222} \mathrm{Rn}\right)$, thoron $\left({ }^{220} \mathrm{Rn}\right)$ gases and their short-lived decay products are also used to assess radiological implications to human body. Radon and thoron are the decay products of ${ }^{226} \mathrm{Ra}$ and ${ }^{232} \mathrm{Th}$, which exist in soil. They are the reason of lungs cancer when inhaled by inhabitants. Inhalation of alpha particles emitted from the short-lived radionuclides of radon and thoron are also hazardous to the respiratory tract. This internal hazard index $H_{i n}$ can be quantified by Eq. (5).

$$
H_{\text {in }}=C_{R a} / 185+C_{T h} / 259+C_{K} / 4810 \leq 1
$$

where $C_{R a}, C_{T h}$ and $C_{K}$ are the activity concentrations of ${ }^{226} \mathrm{Ra},{ }^{232} \mathrm{Th}$ and ${ }^{40} \mathrm{~K}$ in $\mathrm{Bq} \mathrm{kg}{ }^{-1}$, respectively. The internal hazard index should also be less than unity to provide safe levels of radon and thoron and their short-lived daughters for the respiratory organs of individuals.

\section{EXPERIMENTAL METHODS}

\section{Study area and sampling}

Tual and Kei islands are located in eastern Indonesia between $5^{\circ}-6^{\circ} 5^{\prime}$ south latitude and $131^{\circ} 50^{\prime}-135^{\circ} 15^{\prime}$ east longitude (Fig. 1). The islands are comprised of three main islands, Kei Dullah (Tual), Kei Kecil (literally, "Small Kei") and Kei Besar (literally, "Big Kei"), as well as other small islands. The islands are on the edge of the Banda Sea, south of the Bird's Head Peninsula of New Guinea and the group of Indonesian islands that are separated by deep water from both the Asian and Australian continents. Tual and Kei Kecil have a larger population than the others, and are flat. Kei Besar is a narrow and mountainous island, stretching about 85 kilometers from southwest to northeast, and reaching elevations over 800 meters and geologically older than others. Limestone dominates on most of the by fringing reefs surrounded islands $[21,22]$.
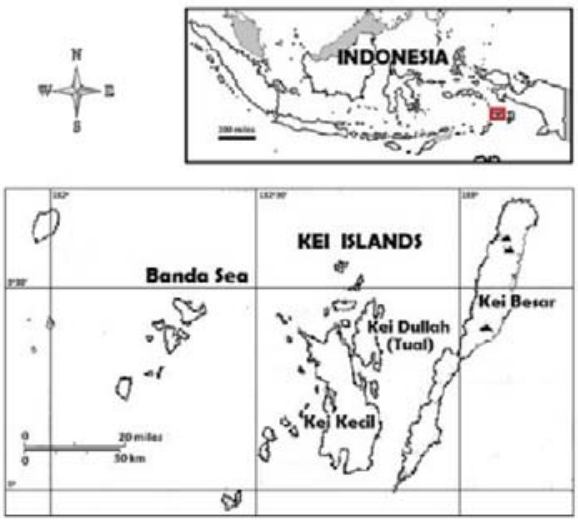

Fig. 1. The map of Tual and Kei islands.

\begin{tabular}{|c|c|c|c|c|c|c|c|c|c|c|c|}
\hline \multirow{2}{*}{$\begin{array}{l}\text { Sample } \\
\text { number }\end{array}$} & \multicolumn{2}{|c|}{ Coordinates } & \multicolumn{9}{|c|}{ Activity concentration $\left(\mathrm{Bq} \mathrm{kg}^{-1}\right)$} \\
\hline & \multirow{2}{*}{$\frac{S}{5,47.4^{\prime \prime}}$} & \multirow{2}{*}{$\begin{array}{c}\mathrm{E} \\
132^{0} 45^{\prime} 8.6^{\prime \prime}\end{array}$} & \multicolumn{3}{|c|}{${ }^{226} \mathrm{Ra}$} & \multicolumn{3}{|c|}{${ }^{232} \mathrm{Th}$} & \multicolumn{3}{|c|}{${ }^{40} \mathrm{~K}$} \\
\hline $\mathrm{S}_{1}$ & & & 849 & \pm & 54 & 38.34 & \pm & 2.60 & 15.81 & \pm & 3.24 \\
\hline $\mathrm{S}_{2}$ & $5^{0} 31^{\prime} 28.6^{\prime \prime}$ & $132^{0} 47^{\prime} 43.1^{\prime \prime}$ & 7.50 & \pm & 0.72 & 0.99 & \pm & 0.13 & 19.52 & \pm & 1.79 \\
\hline $\mathrm{S}_{3}$ & $5^{0} 36^{\prime} 33.5^{\prime \prime}$ & $132^{0} 47^{\prime} 53.9^{\prime \prime}$ & 822 & \pm & 50 & 28.27 & \pm & 2.43 & 26.50 & \pm & 5.11 \\
\hline $\mathrm{S}_{4}$ & $5^{0} 43^{\prime} 15.4 "$ & $132^{0} 44^{\prime} 51.4^{\prime \prime}$ & 3094 & \pm & 179 & 48.88 & \pm & 3.26 & 9.71 & \pm & 2.16 \\
\hline $\mathrm{S}_{5}$ & $5^{0} 48^{\prime} 57.2^{\prime \prime}$ & $132^{0} 46^{\prime} 17.8^{\prime \prime}$ & 1280 & \pm & 75 & 33.18 & \pm & 3.17 & 33.32 & \pm & 5.70 \\
\hline $\mathrm{S}_{6}$ & $5^{0} 53^{\prime} 27.9^{\prime \prime}$ & $132^{\circ} 47^{\prime} 30.5^{\prime \prime}$ & 2337 & \pm & 136 & 91.82 & \pm & 5.56 & 30.35 & \pm & 4.00 \\
\hline $\mathrm{S}_{7}$ & $5^{0} 46^{\prime} 01.7^{\prime \prime}$ & $132^{\circ} 43^{\prime} 13.8^{\prime \prime}$ & 3171 & \pm & 190 & 93.55 & \pm & 6.42 & 2.97 & \pm & 0.70 \\
\hline $\mathrm{S}_{8}$ & $5^{0} 44^{\prime} 00.5^{\prime \prime}$ & $132^{\circ} 41^{\prime} 15.0^{\prime \prime}$ & 4104 & \pm & 387 & 116 & \pm & 13 & 20.35 & \pm & 4.55 \\
\hline $\mathrm{S}_{9}$ & $5^{0} 41^{\prime} 59.2^{\prime \prime}$ & $132^{\circ} 39^{\prime} 16.2^{\prime \prime}$ & 4018 & \pm & 379 & 144 & \pm & 15 & 35.00 & \pm & 5.97 \\
\hline$S_{10}$ & $5^{0} 39^{\prime} 36.0^{\prime \prime}$ & $132^{0} 38^{\prime} 42.7 "$ & 6326 & \pm & 594 & 157 & \pm & 15 & 32.70 & \pm & 4.04 \\
\hline $\mathrm{S}_{11}$ & $5^{0} 37^{\prime} 53.9^{\prime \prime}$ & $132^{0} 45^{\prime} 26.6^{\prime \prime}$ & 5403 & \pm & 508 & 155 & \pm & 16 & 19.92 & \pm & 3.73 \\
\hline $\mathrm{S}_{12}$ & $5^{0} 53^{\prime} 29.3^{\prime \prime}$ & $132^{\circ} 43^{\prime} 30.4^{\prime \prime}$ & 311 & \pm & 30 & 32.58 & \pm & 4.21 & 98.91 & \pm & 11.75 \\
\hline $\mathrm{S}_{13}$ & $5^{0} 39^{\prime} 41.2^{\prime \prime}$ & $132^{0} 59^{\prime} 56.6^{\prime \prime}$ & 63.65 & \pm & 6.40 & 34.08 & \pm & 3.64 & 76.88 & \pm & 8.14 \\
\hline $\mathrm{S}_{14}$ & $5^{0} 36^{\prime} 03.1^{\prime \prime}$ & $133^{0} 02^{\prime} 16.2^{\prime \prime}$ & 512 & \pm & 49 & 57.74 & \pm & 5.73 & 16.22 & \pm & 2.10 \\
\hline $\mathrm{S}_{15}$ & $5^{0} 54^{\prime} 47.4^{\prime \prime}$ & $132^{0} 52^{\prime} 57.9^{\prime \prime}$ & 126 & & 12.33 & 13.75 & \pm & 1.71 & 22.91 & \pm & 2.99 \\
\hline Range & & & 7.50 & - & 6326 & 0.99 & - & 157 & 2.97 & - & 98.91 \\
\hline Average & & & 2162 & \pm & 177 & 69.68 & \pm & 6.52 & 30.74 & \pm & 4.40 \\
\hline
\end{tabular}

Table 1. The activity concentrations of ${ }^{226} \mathrm{Ra},{ }^{232} \mathrm{Th}$, and ${ }^{40} \mathrm{~K}$ in soil samples and air absorbed dose rate from gamma radiation. 
Soil samples were collected from Tual, Kei Kecil and Kei Besar islands at the flat, open and undisturbed area. The coordinates of all sampling points were recorded using the Global Positioning System device (GPS Map 60CSx, Garmin Ltd). 15 surface soil samples (i.e., S1 to S15) were taken to a depth of $5 \mathrm{~cm}$ by shovel at each point. Table 1 shows the coordinates of each sampling location from which the soil samples were collected. After the humus layer of soil which contains decayed organic matter and extraneous material such as plant roots were removed, about $2 \mathrm{~kg}$ of samples was wrapped in polyethylene bag and labelled according to the name of the site where it was taken

\section{Sample preparation and measurement}

The collected soil samples were homogenized and oven dried at $110{ }^{\circ} \mathrm{C}$ for about one day to a constant weight to remove any available moisture. Then, the soil samples were crushed into fine powder and sieved through a $2 \mathrm{~mm}$ sieve $/ 10$ mesh size in order to remove other materials such as organic, stones and lumps. Afterwards, the homogenized soils were introduced into 1 liter Marinelli beakers and carefully sealed in order to prevent trapped radon gas from escape. They were allowed to stand for at least 4 weeks in order to be established the secular equilibrium between the long-lived parent nuclides of ${ }^{226} \mathrm{Ra}$ and ${ }^{232} \mathrm{Th}$, and their short-lived daughters before measurement $[12,18]$.

The activity concentrations of ${ }^{226} \mathrm{Ra},{ }^{232} \mathrm{Th}$ and ${ }^{40} \mathrm{~K}$ in soil samples were measured using ORTEC Ptype coaxial high purity Germanium (HPGe) detector gamma spectrometry system which has a $50 \%$ relative efficiency. The detector was located inside a cylindrical lead shield and lined with various layers of tin and copper on all internal surfaces respectively. All spectrometer measurement systems were installed in the counting laboratory in the basement to reduce the external gamma-ray background in the measured spectrum. The energy and efficiency calibration of the gamma spectrometry system were made using a solid nuclide mixture of gamma reference materials sealed in standard Marinelli beakers with an active volume of 1 liter and International Atomic Energy Agency (IAEA) reference materials RGU-1, RGTh-1 and RGK-1. Background measurements were performed under the same conditions of sample measurements and used to correct the net peak area of gamma rays of measured radionuclides. Quality assurance was additionally guaranteed by regular participations in national and international intercompararison exercises. The gamma energy peaks of $295 \mathrm{keV}$ and $352 \mathrm{keV}$ from ${ }^{214} \mathrm{~Pb}$ and $609.31 \mathrm{keV}$ from ${ }^{214} \mathrm{Bi}$ were used to determine ${ }^{226} \mathrm{Ra}$. The gamma energy peaks of $238.6 \mathrm{keV}$ from ${ }^{212} \mathrm{~Pb}$, $911.2 \mathrm{keV}$ and $969 \mathrm{keV}$ from ${ }^{228} \mathrm{Ac}$ and $583 \mathrm{keV}$ from ${ }^{208} \mathrm{Tl}$ were used to determine the ${ }^{232} \mathrm{Th}$. Whereas that of ${ }^{40} \mathrm{~K}$ was determined from the gamma energy peak of $1460.8 \mathrm{keV}[23,24]$.

\section{RESULTS AND DISCUSSION}

The performance of gamma-ray spectrometry system in the measurements of the ${ }^{226} \mathrm{Ra},{ }^{232} \mathrm{Th}$ and ${ }^{40} \mathrm{~K}$ in IAEA reference materials showed relatively good agreement within a relative deviation of $5 \%$, $6 \%$ and $4 \%$, respectively. The minimum detectable concentration (MDC) of the counting system for the radionuclides was $0.2 \mathrm{~Bq} \mathrm{~kg}^{-1}$ for ${ }^{226} \mathrm{Ra}, 0.3 \mathrm{~Bq} \mathrm{~kg}^{-1}$ for ${ }^{232} \mathrm{Th}$ and $1.4 \mathrm{~Bq} \mathrm{~kg}^{-1}$ for ${ }^{40} \mathrm{~K}$ with the $95 \%$ confidence level.

The results of activity concentration measurements in the soil samples are shown in Table 1 . The activity concentrations of ${ }^{226} \mathrm{Ra}$ ranged from $7.50 \pm 0.72 \mathrm{~Bq} \mathrm{~kg}^{-1}$ to $6326 \pm 594 \mathrm{~Bq} \mathrm{~kg}^{-1}$ with the average concentration of $2162 \pm 177 \mathrm{~Bq}$ $\mathrm{kg}^{-1}$. The soil samples have ${ }^{226} \mathrm{Ra}$ activity concentrations more than 62 times higher than the world average value of $35 \mathrm{~Bq} \mathrm{~kg}^{-1}[12,17]$. The activity concentrations of ${ }^{232} \mathrm{Th}$ ranged from $0.99 \pm 0.13 \mathrm{~Bq} \mathrm{~kg}^{-1}$ to $157 \pm 15 \mathrm{~Bq} \mathrm{~kg}^{-1}$ with the average value of $69.68 \pm 6.52 \mathrm{~Bq} \mathrm{~kg}^{-1}$. The activity concentrations of ${ }^{232} \mathrm{Th}$ in soil samples were found about 2.3 times more than the world average value of $30 \mathrm{~Bq} \mathrm{~kg}{ }^{-1}$. These finding show that the activity concentrations of ${ }^{226} \mathrm{Ra}$ and ${ }^{232} \mathrm{Th}$ in the soil samples collected from Tual and Kei islands are higher than world average values. The presence of these higher values clearly indicates the rich distribution of heavy minerals in the present study area. However, in contrast the activity concentration of ${ }^{40} \mathrm{~K}$ in the soil samples is much lower than the other radionuclides $\left({ }^{226} \mathrm{Ra}\right.$ and $\left.{ }^{232} \mathrm{Th}\right)$. The activity concentrations of ${ }^{40} \mathrm{~K}$ ranged from $2.97 \pm 0.70 \mathrm{~Bq} \mathrm{~kg}^{-1}$ to $98.91 \pm 11.75 \mathrm{~Bq} \mathrm{~kg}^{-1}$ with the average value of $30.74 \pm 4.40 \mathrm{~Bq} \mathrm{~kg}^{-1}$. The activity concentrations of ${ }^{40} \mathrm{~K}$ in all sampling sites are much lower than the world average values of $400 \mathrm{~Bq} \mathrm{~kg}^{-1}$.

The distributions of ${ }^{226} \mathrm{Ra},{ }^{232} \mathrm{Th}$, and ${ }^{40} \mathrm{~K}$ in Tual and Kei islands soils are shown in Fig. 2. The average activity concentrations of the radionuclides in the collected soils were found in the following order: ${ }^{226} \mathrm{Ra}>{ }^{232} \mathrm{Th}>{ }^{40} \mathrm{~K}$. The total activity concentration of the three radionuclides $\left({ }^{226} \mathrm{Ra},{ }^{232} \mathrm{Th}\right.$, and $\left.{ }^{40} \mathrm{~K}\right)$ in the collected soil samples ranged from $28.01 \mathrm{~Bq} \mathrm{~kg}^{-1}$ to $6515.7 \mathrm{~Bq} \mathrm{~kg} \mathrm{~kg}^{-1}$ with the average value of $2262 \mathrm{~Bq} \mathrm{~kg}$. The concentration of ${ }^{226} \mathrm{Ra}$ is approximately $96 \%$ of 
the total gamma activity of the soil samples, which indicates that the specific activity due to ${ }^{226} \mathrm{Ra}$ is the largest contributor to the total activity for all sampling sites.

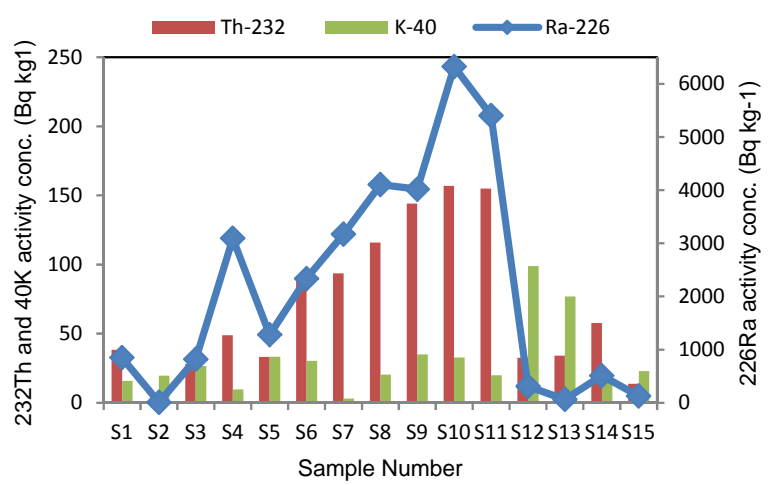

Fig. 2. The spatial distribution of the activity concentration of ${ }^{226} \mathrm{Ra},{ }^{232} \mathrm{Th}$, and ${ }^{40} \mathrm{~K}$.

In order to evaluate the radiological effects from the radioactivity of the soils containing ${ }^{226} \mathrm{Ra}$, ${ }^{232} \mathrm{Th}$, and ${ }^{40} \mathrm{~K}$, the different radiological parameters are presented in Table 2 such as absorbed dose rate $(D)$, annual effective dose equivalent $(E)$, radium equivalent activity $\left(R a_{e q}\right)$, external and internal hazard indexes $\left(H_{e x}\right.$ and $\left.H_{i n}\right)$. The values of absorbed dose rates in air as can be seen in Table 2 are ranged from $4.88 \mathrm{nGy} \mathrm{h}^{-1}$ to $3018.80 \mathrm{nGy} \mathrm{h}$ with the average value of $1042 \mathrm{nGy} \mathrm{h}^{-1}$, which is much higher (18 times) than the world average value $\left(57 \mathrm{nGy} \mathrm{h}^{-1}\right)$ [12]. Most of the sampling sites are having higher values than the average value of global primordial radiation.
The outdoor annual effective dose rate values of Tual and Kei islands vary from $0.01 \mathrm{mSv}$ year ${ }^{-1}$ to $3.70 \mathrm{mSv}$ year ${ }^{-1}$, and the average value was found to be $1.28 \mathrm{mSv}$ year $^{-1}$. The world average annual effective dose equivalent from outdoor terrestrial gamma radiation is $0.07 \mathrm{mSv}$ year ${ }^{-1}$. The obtained annual outdoor effective dose values for the area of Tual and Kei islands are much higher than the average worldwide value for individual members of the public. Highest value is observed at $\mathrm{S}_{10}\left(3.70 \mathrm{mSv} \mathrm{y}^{-1}\right)$, which is 53 times higher than recommended level.

The calculated values of radium equivalent $\left(R a_{e q}\right)$ for the soil samples from Tual and Kei islands vary from $10.42 \mathrm{~Bq} \mathrm{~kg}^{-1}$ to $6553.03 \mathrm{~Bq} \mathrm{~kg}^{-1}$ with the average value of $2264 \mathrm{~Bq} \mathrm{~kg}^{-1}$. This average value of $R a_{e q}$ in this study is higher (6 times) than the recommended maximum value of $370 \mathrm{~Bq} \mathrm{~kg}^{-1}$. The external and internal hazard index for this study area ranged from 0.03 to 17.71 with the average value of 6.12 and 0.05 to 34.81 with the average value of 11.96 , respectively. The calculated values for external and internal hazard indexes for soil samples are higher than unity (permissible level). The values of hazard indexes $\left(H_{e x}\right.$ and $H_{i n)}$ must not exceed dose equivalent limit of $1 \mathrm{mSv} \mathrm{y}^{-1}$ in order to radiation hazard to be negligible $[20,25]$. Exceedance of the recommended upper limit is noted in 12 sampling sites. This exceedance in these sites is due to the higher concentration of radionuclides mostly the ${ }^{226} \mathrm{Ra}$ and then followed by the contributions of ${ }^{232} \mathrm{Th}$ and ${ }^{40} \mathrm{~K}$.

Table 2. The radiological hazard parameters of soil.

\begin{tabular}{cccccc}
\hline $\begin{array}{c}\text { Sample } \\
\text { number }\end{array}$ & $\begin{array}{c}\text { Absorbed dose rate } \\
\left(\mathrm{D}, \mathrm{nGy} \mathrm{h}^{-1}\right)\end{array}$ & $\begin{array}{c}\text { Annual effective } \\
\text { dose equivalent } \\
\left(\mathrm{E}, \mathrm{mSv} \mathrm{y}^{-1}\right)\end{array}$ & $\begin{array}{c}\text { Radium } \\
\text { equivalent activity } \\
\left(\mathrm{Ra}_{\text {eq }}, \mathrm{Bq} \mathrm{kg}^{-1}\right)\end{array}$ & $\begin{array}{c}\text { External } \\
\text { hazard index } \\
\left(H_{e x}\right)\end{array}$ & $\begin{array}{c}\text { Internal } \\
\text { hazard index } \\
\left(H_{\text {in }}\right)\end{array}$ \\
\hline $\mathrm{S}_{1}$ & 416.05 & 0.51 & 905.04 & 2.45 & 4.74 \\
$\mathrm{~S}_{2}$ & 4.88 & 0.01 & 10.42 & 0.03 & 0.05 \\
$\mathrm{~S}_{3}$ & 397.94 & 0.49 & 864.47 & 2.34 & 4.56 \\
$\mathrm{~S}_{4}$ & 1459.36 & 1.79 & 3164.65 & 8.55 & 16.92 \\
$\mathrm{~S}_{5}$ & 612.79 & 0.75 & 1330.01 & 3.59 & 7.05 \\
$\mathrm{~S}_{6}$ & 1136.42 & 1.39 & 2470.64 & 6.68 & 12.99 \\
$\mathrm{~S}_{7}$ & 1521.63 & 1.87 & 3305.01 & 8.93 & 17.50 \\
$\mathrm{~S}_{8}$ & 1966.96 & 2.41 & 4271.45 & 11.54 & 22.64 \\
$\mathrm{~S}_{9}$ & 1944.75 & 2.39 & 4226.62 & 11.42 & 22.28 \\
$\mathrm{~S}_{10}$ & 3018.80 & 3.70 & 6553.03 & 17.71 & 34.81 \\
$\mathrm{~S}_{11}$ & 2590.64 & 3.18 & 5626.18 & 15.21 & 29.81 \\
$\mathrm{~S}_{12}$ & 167.48 & 0.21 & 365.21 & 0.99 & 1.83 \\
$\mathrm{~S}_{13}$ & 53.20 & 0.07 & 118.30 & 0.32 & 0.49 \\
$\mathrm{~S}_{14}$ & 272.10 & 0.33 & 596.82 & 1.61 & 2.99 \\
$\mathrm{~S}_{15}$ & 67.47 & 0.08 & 147.43 & 0.40 & 0.74 \\
\hline Range & $4.88-3018.80$ & $0.01-3.70$ & $10.42-6553.03$ & $0.03-17.71$ & $0.05-34.81$ \\
\hline Average & 1042 & 1.28 & 2264 & 6.12 & 11.96 \\
\hline
\end{tabular}


Table 3. Comparison of outdoor gamma dose levels in the highlevel natural background areas in the world.

\begin{tabular}{llcc}
\hline Country & \multicolumn{1}{c}{ Area } & $\begin{array}{c}\text { Absorbed Dose } \\
\text { rate in air }\left(\mathrm{nGy} \mathrm{h}^{-1}\right)\end{array}$ & $\begin{array}{c}\text { Annual effective } \\
\text { dose equivalent } \\
\left(\mathrm{E}, \mathrm{mSv} \mathrm{y}^{-1}\right)\end{array}$ \\
\hline Brazil & Guarapari & $90-90000$ & $0.11-110.38$ \\
China & Yangjiang & $(370)$ & $(0.45)$ \\
India & Kerala & $200-4000$ & $0.25-4.91$ \\
Iran & Ramsar & $70-17000$ & $0.09-20.85$ \\
Present & $\begin{array}{l}\text { Tual and Kei } \\
\text { study }\end{array}$ & $4.88-3018.80(1042)$ & $0.01-3.70(1.28)$ \\
\hline Note: ( ) Average value & &
\end{tabular}

Compared to the high natural background radiation areas (HNBRAs) in the world such as Yangjiang, China; Kerala, India; Guarapari, Brazil; and Ramsar, Iran, the values of outdoor external dose rate in this study area are comparable. The values obtained in this study and some of the world HNBRAs are presented in Table 3 [26]. This indicates that Tual and Kei islands are naturally high in natural radioactivity and primarily due to the presence of very high amounts of ${ }^{226} \mathrm{Ra}$.

\section{CONCLUSION}

The evaluation of natural radionuclides levels in the soil samples collected from Tual and Kei islands, Indonesia was conducted by gamma-ray spectrometry. Except for ${ }^{40} \mathrm{~K}$, most of the activity concentrations of ${ }^{226} \mathrm{Ra}$ and ${ }^{232} \mathrm{Th}$ in soil samples are higher than the worldwide average values. The activity concentrations levels of ${ }^{226} \mathrm{Ra}$ in soil of the study area are significantly higher than those of ${ }^{40} \mathrm{~K}$ and ${ }^{232} \mathrm{Th}$. This means that ${ }^{226} \mathrm{Ra}$ is the largest contributor for exposure of radiation to the general public. There is a significant radiological hazard $\left(>1 \mathrm{mSv} \mathrm{y}^{-1}\right)$ to the inhabitants of the Tual and Kei islands area. It has also been shown that these areas have comparably high natural background radiation levels as in some of the wellknown high natural background radiation areas in the world.

\section{ACKNOWLEDGMENT}

The authors wish to thank the National Nuclear Energy Agency (BATAN), Indonesia for the financial support to this work. The authors also gratefully acknowledge reviewers for their comments which improved this manuscript and all staff of the Radioecology Division, Center for Safety Technology and Radiation Metrology for their kind cooperation.

\section{REFERENCES}

1. F.C.A. Ribeiro, J.I.R. Silva, E.S.A. Lima et al., J. Environ. Radioact. 182 (2018) 34.

2. M.A. Arnedo, J.G. Rubiano, H. Alonso et al., J. Environ. Radioact. 166 (2017) 242.

3. S. Forkapic, J. Vasin, I. Bikit et al., J. Environ. Radioact. 166 (2017) 104.

4. I.M. Zougrou, S. Stoulos, N. Kantiranis et al., J. Environ. Radioact. 193 (2018) 1.

5. M. Al-Hilal and M. Aissa, J. Environ. Radioact. 140 (2015) 1.

6. B. Goddard, E. Bosc, S. Al Hassani et al., J. Environ. Radioact. 189 (2018) 191.

7. Y. Omori, S. Tokonami, T. Ishikawa et al., J. Radioanal. Nucl. Chem. 306 (2015) 317.

8. A.S. Aliyu and A.T. Ramli, Radiat. Meas. 73 (2015) 51.

9. V. Ramasamy, M. Sundarrajan, G. Suresh et al., App. Radiat. Iso. 85 (2014) 1.

10. M. Sohrabi, M. Radiat. Meas. 50 (2013) 166.

11. K. Saini and B.S. Bajwa, App. Radiat. Iso. 127 (2017) 73.

12. H. Al-Sulaiti, K.S.A. Mugren, D.A. Bradley et al., Radiat. Phys. Chem. 140 (2017) 132.

13. G. Cinelli, T. Tollefsen, P. Bossew et al., J. Environ. Radioact. 196 (2019) 240.

14. Syarbaini, Kusdiana and D. Iskandar, International Journal of Sustainable Energy and Environment 3 (2015) 1.

15. Syarbaini and G. Suhariyono, Atom Indonesia 42 (2016) 47.

16. Syarbaini and A. Setiawan, Atom Indonesia 41 (2015) 41.

17. Y.J. Huang, C.F. Chen, Y.C. Huang et al., Radiat. Phys. Chem. 107 (2015) 82.

18. Amanjeet, A. Kumar, S. Kumar et al., J. Radiat. Res. Appl. Sci. 10 (2017) 283.

19. E.S. Joel, O. Maxwell, O.O. Adewoyin et al., Radiat. Phys. Chem. 144 (2018) 43.

20. A.D. Bajoga, N. Alazemi, P.H. Regan et al., Radiat. Phys. Chem. 116 (2015) 305.

21. A. Kurniasih, N. Qadaryati and R. Setyawan, IOP Conf. Ser. Earth Environ. Sci. 279 (2019) 1.

22. T.R. Charlton, S.J. Kaye, H. Samodra et al., Mari. Petrol. Geol. 8 (1991) 62.

23. L. Guidotti, F. Carini, R. Rossi et al., J. Environ. Radioact. 142 (2015) 36. 
24. M.R. Kardan, N. Fathabdi, A. Attarilar et al., J. Environ. Radioact. 178 (2017) 168.

25. Anonymous, 1990 Recommendations of the International Commission on Radiological
Protection, ICRP Publication 60, Ann. ICRP 21 (1991) 1.

26. P.K. Shetly and Y. Narayama, J. Environ. Radioact. 101 (2010) 1043. 